\title{
Characterization of Brazilian Bentonite Organoclays as Sorbents of Petroleum-derived Fuels
}

\author{
Caroline Bertagnolli, Meuris Gurgel Carlos da Silva*
}

\author{
School of Chemical Engineering, University of Campinas - UNICAMP, \\ CEP 13083-852, Campinas, SP, Brazil
}

Received: July 13, 2011; Revised: January 24, 2012

\begin{abstract}
This work focused on preparing and characterizing Brazilian bentonite clay through the use of quaternary ammonium salt so as to apply it as a sorbent for petroleum-derived fuels. Bentonite clay was organophilizated by the intercalation of quaternary ammonium salts such as cetyl-pyridinium chloride and benzalkonium chloride. The resulting materials were characterized by $\mathrm{X}$-ray diffraction, scanning electron microscopy, energy dispersive X-ray spectroscopy, $\mathrm{N}_{2}$ physisorption and infrared spectroscopy techniques. The clay similarity with petroleum-derived fuels, gasoline and diesel oil were defined by sorption and swelling tests. The increase in basal spacing and the appearance of absorption bands related to the $\mathrm{CH}_{2}$ and $\mathrm{CH}_{3}$ groups confirm the efficiency of Brazilian organoclays. Removal percentages between 50 and 60 for benzene, toluene and xylene indicate the potential of organoclay in the remediation of areas contaminated by petroleum-derived fuels.
\end{abstract}

Keywords: "Verde-Lodo" clay, quaternary ammonium salt, X-ray diffraction, infrared spectroscopy

\section{Introduction}

The exploration, refining, and transportation of petroleum and its derivatives have become largely responsible for the pollution of soil and water by organic compounds due their increased scale of production and use. Gas stations represent a potential source of contamination of soils and groundwater due to the products they manipulate (gasoline, diesel oil and ethanol) and the manner in which these are stored and sold. Although large accidental oil spills are troubling, Tiburtius et al. (2005) ${ }^{1}$ consider small and continuous leaks as well as fuel distribution depots as the main source of contamination. Fuelling activities and vehicle washing cause fuel loss which is carried by rain reaching rivers, groundwater and pluvial sewers - in addition to contamination from leaks in old, cracked and corroded storage tanks ${ }^{2}$.

In Brazil, there are no statistics for underground fuel tank contamination, although the São Paulo state environmental company has estimated that gas stations are responsible for $78 \%$ of all contaminated areas ${ }^{3}$.

Petroleum-derived fuels contain highly toxic compounds to human health including aromatic fractions (benzene, toluene, ethyl benzene and xylene - BTEX). As BTEX have the physico-chemical properties that make them more soluble in water, major pollution problems have been attributed to them ${ }^{4,5}$. Aromatic hydrocarbons from gasoline, for example, have greater mobility in water and water-soil systems due to the lower partition coefficient between octanol-water ${ }^{6}$. Several processes are available to treat groundwater impacted by petroleum hydrocarbons, such as bioremediation, air spray and monitored natural attenuation? These treatment processes are complex and relatively long.

*e-mail: meuris@feq.unicamp.br
Therefore, the use of organoclays for sorption of organic compounds, either as a reactive barrier or as adsorption systems has been found effective for containment of leaks from underground fuel storage tanks, preventing or controlling environmental pollution ${ }^{8-11}$. Many studies have evaluated the use of organoclays in contaminant remediation. Cationic surfactants controlled migration of nonionic organic compounds ${ }^{12}$. Burns et al. (2003) ${ }^{13}$ investigated the adsorption capacity and retention of hydrocarbons of gasoline by bentonite clay modified with hexadecyltrimethylammonium and triethylbenzylammonium. Although a mixture of hydrocarbons can be found at polluted sites, sorption using organoclay was evaluated for a single contaminant in most studies.

Clay minerals can change their naturally hydrophilic character into organophilic, acting as sorbents for organic compounds derived from petroleum such as gasoline, diesel oil, xylene and toluene ${ }^{14}$. The organophilization consists of quaternary ammonium salt addition with a chain of twelve or more carbon atoms to aqueous dispersions at an inorganic cation change for alkylammonium cations ${ }^{15}$. The salt molecules reduce the clay superficial tension when it disperses into organic medium ${ }^{16}$. According Kowalska et al. $(1994)^{17}$, clay interactions with organic compounds involve the electrostatic charge on the surface of silicate, being influenced by molecular weight, chain length and functional group of the adsorbed organic molecule.

The bentonite group is largely used in the preparation of organoclay, due to small crystal dimensions, high superficial area and cation exchange capacity ${ }^{18}$. Moreover, the clays, particularly those from the Northeast of Brazil, occur superimposed on other mineral deposits of great commercial 
interest, such as gypsum. This fact could help reduce the extraction costs of that mineral in these deposits.

Thus, this work was aimed at preparing and characterizing Brazilian organoclays in order to evaluate their interactions with petroleum-derived fuels so as to use them in the remediation of contaminated areas. Several characterization techniques were employed to identify the changes in clay that enable its applicability as a sorbent.

\section{Material and methods}

\subsection{Clay preparation}

Bentonite "Verde-Lodo" clay from Paraíba, located in the Northeastern region of Brazil, was used. The cation exchange capacity (CEC) is of $87.53 \mathrm{mEq} .100 \mathrm{~g}^{-1}$ (estimate determined through ammonium cation exchange $\mathrm{e}^{19}$ ). Initially, clays were purified through sodium exchange: carbonate sodium solution and clay were mixed under heat, being stirred until boiling. This first pre-treatment is performed with sodium ions, which are easily exchangeable as they are a monovalent ion and are usually found in large numbers between clay layers. After heating, the dispersion was stirred for another 20 minutes for cooling and subsequent benzalkonium chloride or cetyl-pyridinium chloride surfactant addition at 1:1 ratio of CEC's clay ${ }^{20}$. The clay samples were identified as VL-natural, VL-benzal (with benzalkonium chloride salt) and VL-cetyl (with cetylpyridinium chloride salt).

\subsection{Clay characterization}

The obtained material was characterized through several techniques and the organoclay swelling and sorption in petroleum-derived fuels were measured. The Bragg angular zone was explored by X-ray diffraction (XRD) in Shimadzu equipment, XDR 7000, $\mathrm{K} \alpha$ cooper radiation $(\lambda=1.54 \AA$ ), monitoring the diffraction $2 \theta$ angles, 0.02 degree step size from 1.5 to $30^{\circ}$, 1 second signal accumulation time, $40 \mathrm{kV}$ voltage and $30 \mathrm{~mA}$ current. In order to evaluate the adsorbent morphology, a scanning electron microscopy (SEM) using LEO equipment, LEO 440 , with $500 \times$ power was performed. The energy dispersive X-ray technique (EDX) enables qualitative evaluation of chemical compositions. The surface area and the volume of pores and micropores were obtained through $\mathrm{N}_{2}$ physisorption (BET method) at $77 \mathrm{~K}$, using a special sample tube with bulb. These analyses were performed using a Micromeritics ${ }^{\circledR}$ Gemini III 2375 Surface Area Analyzer device using the BET method. Infrared spectra were collected using a Spectrum One FT-IR spectrometer, Perkin Elmer. Spectra were collected over the spectral range $4000-400 \mathrm{~cm}^{-1}$. Samples consisted of anhydrous $\mathrm{KBr}$ pellets mixed with clay.

\subsection{Petroleum-derived sorption}

Organoclay swelling into petroleum-derived fuels was measured in gasoline and diesel oil. $1.0 \mathrm{~g}$ of clay was gradually added to $50 \mathrm{~mL}$ of petroleum-derived fuels contained into a graduated cylinder, without stirring. After 24 hours, clay column volume was measured; after the stirring dispersion and another 24 hours, swelling was measured again. This test was performed in conformity with Foster $(1953)^{21}$, with some adjustments proposed by Diaz (1994) $)^{15}$.

The organic liquids sorption capacity was measured following a method based on ASTM ${ }^{\circledR} 716-82$ and ASTM ${ }^{\circledR}$ F726-99 standard $^{22,23}$. At sorption tests, $1.0 \mathrm{~g}$ of clay was placed into a small metal basket of a certain known weight, and subsequently, in contact with the petroleum-derivative for 15 minutes, suspended for 15 seconds to remove its derivative excess and measured again. The organic sorption was obtained through the difference between initial and final weight.

In addition to sorption and swelling tests, the removal percentage of benzene, toluene and xylene (BTX) in gasoline by organoclay was also evaluated. $100 \mathrm{~mL}$ of $15 \%$ volume of gasoline in water was placed in contact with $1 \mathrm{~g}$ of organoclay for 48 hours $^{24}$ and the initial and final concentrations of benzene, toluene and xylene compounds were determined by headspace gas chromatography (Shimadzu, 2010, detector GCMS-QP plus). BTX removal was determined due to the presence of large amounts of these compounds in petroleum-derived fuels and high toxicity. The tests were kept under constant stirring of $250 \mathrm{rpm}$, with temperature control at $25{ }^{\circ} \mathrm{C}$. To minimize vaporization losses, the tops of the tubes were covered with aluminum foil before caps were screwed onto them.

\section{Results and Discussion}

\subsection{Characterization}

\subsubsection{Basal spacing evaluation by X-ray diffraction}

The diffractograms obtained from natural and organophilic clay were shown in Figure 1. Thus, it is possible to observe the presence of montmorillonite and quartz, typical of this type of clay in which smectite is the predominant clay mineral ${ }^{18}$. The basal spacing of the natural clay changed from 15.2 to $23.9 \AA$ for VL-benzal and to $21.6 \AA$ for VL-cetyl. The significant increase in $\mathrm{d}_{001}$ of organoclays shows the effective quaternary ammonium

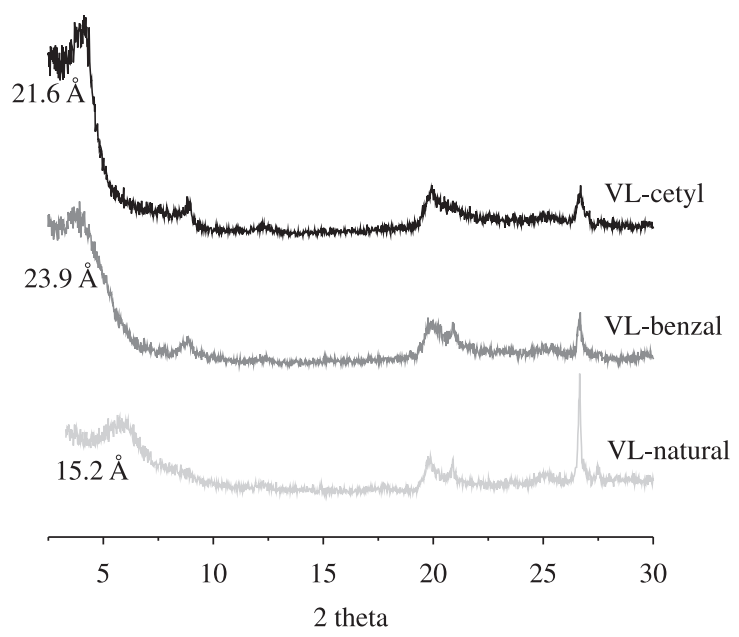

Figure 1. Clay diffractograms. 
cation intercalation in the layers. According to the measured basal spacing, intercalated alkylammonium cations in VLbenzal acquire a paraffin-type orientation, while the VLcetyl clay was a pseudo-trimolecular layer ${ }^{25}$.

\subsubsection{Morphology and qualitative chemical composition}

The scanning electron microscopy (SEM) results for natural and organoclay samples are presented in Figure 2. The solid porous nature was verified through various sized irregular blades and many similar aspects, even after the samples had been treated with quaternary salt.

Bentonite qualitative chemical analysis is shown in Figure 3. The significant $\mathrm{Si}$ and $\mathrm{Al}$ presence could be observed in all clays. These are the main components of clay minerals ${ }^{18} . \mathrm{Mg}$ and $\mathrm{Fe}$ were isomorphous substitution elements and $\mathrm{Na}$ was the exchange cation. $\mathrm{C}$ and $\mathrm{Cl}$ peaks appear in organoclays (Figure 3b,c), coming from intercalated quaternary salt. Na peaks disappeared, confirming that most Na cations had been replaced by alkylammonium cations, and were eliminated during clay filtration and washing.

\subsubsection{Surface area and pore characteristics}

The obtained values for surface area through BET method for natural and organoclay samples are found in Table 1. Using BET adsorption isotherms, micropore $\left(\mathrm{V}_{\mathrm{mi}}\right)$ and mesopore $\left(\mathrm{V}_{\text {mes }}\right)$ volumes were obtained by reading adsorbed volume $\left(\mathrm{V}_{\text {ads }}\right)$ at $\mathrm{P} / \mathrm{P}_{0}=0.10$ and 0.95 , expressed by Equations 1 and $2^{[26]}$.

$\mathrm{V}_{\mathrm{mi}}=\mathrm{V}_{\mathrm{ads}}\left(\mathrm{P} / \mathrm{P}_{0}=0.10\right)$

$\mathrm{V}_{\text {mes }}=\mathrm{V}_{\text {ads }}\left(\mathrm{P} / \mathrm{P}_{0}=0.95\right)-\mathrm{V}_{\mathrm{ads}}\left(\mathrm{P} / \mathrm{P}_{0}=0.10\right)$

The organoclay surface area, as well as microand mesopore volumes were drastically reduced after organophilization. These decreases were attributed to the organoclay microstructure, since the quaternary salt intercalation caused an interlayer expansion, as seen on $\mathrm{X}$-ray diffraction analysis, so that salt ions blocked the passage of $\mathrm{N}_{2}$ molecules, occupying active clay sites which might be available for $\mathrm{N}_{2}{ }^{[27,28]}$. Differences among modified clay areas are due to organic cations, which had been layered, and to their interlayer orientation.

\subsubsection{Infrared spectroscopy}

The FTIR spectra for clays are shown in Figure 4. The adsorption bands with the corresponding groups or bonds for each spectrum are found in Table 2. The characteristic vibration peaks of VL-natural were at 470 and $1120 \mathrm{~cm}^{-1}$ corresponding to the clay structure and $\mathrm{Si}-\mathrm{O}-\mathrm{Si}$ and $\mathrm{Si}-\mathrm{O}-$ Al stretching and bending. The peaks at $1040 \mathrm{~cm}^{-1}$ (Si-O stretching) and $523 \mathrm{~cm}^{-1}$ (Si-O bending) were also presented ${ }^{29}$. Sorbed water contributed to $\mathrm{H}-\mathrm{O}-\mathrm{H}$ bending region (1600$1700 \mathrm{~cm}^{-1}$ ) and to $\mathrm{O}-\mathrm{H}$ asymmetric and symmetric stretching region $\left(3100-3700 \mathrm{~cm}^{-1}\right)^{[30]}$. These bands were presented in all studied clays, as shown in Table 2 . The intensity of these bands was reduced with organophilization, because the quaternary salt intercalation, which modified the montmorillonite surface, was modified from hydrophilic to hydrophobic ${ }^{31}$.

Table 1. Specific superficial area and volume of pores of clays by BET method.

\begin{tabular}{lccrc}
\hline Samples & $\begin{array}{c}\text { Superficial Area } \\
\left(\mathbf{m}^{\mathbf{2}} \cdot \mathbf{g}^{-1}\right)\end{array}$ & $\mathbf{R}^{2}$ & $\begin{array}{c}\mathbf{V}_{\text {mi }} \\
\left(\mathbf{c m}^{3} \cdot \mathbf{g}^{-1}\right)\end{array}$ & $\begin{array}{c}\mathbf{V}_{\text {mes }} \\
\left(\mathbf{c m}^{3} \cdot \mathbf{g}^{-1}\right)\end{array}$ \\
\hline VL-natural & 65.414 & 0.999 & 17.024 & 16.711 \\
VL-benzal & 5.659 & 0.999 & 1.128 & 2.514 \\
VL-cetyl & 0.123 & 0.998 & 0.029 & 0.027 \\
\hline
\end{tabular}

Table 2. Bonds identified on the FTIR spectrum.

\begin{tabular}{|c|c|c|c|}
\hline \multirow[t]{2}{*}{ Groups (bond) } & \multicolumn{3}{|c|}{ Wavenumber $\left(\mathrm{cm}^{-1}\right)$} \\
\hline & VL-natural & VL-benzal & VL-cetyl \\
\hline $\mathrm{O}-\mathrm{H}$ asymmetric stretching & 3625 & 3623 & 3627 \\
\hline O-H symmetric stretching & 3427 & 3435 & 3427 \\
\hline $\mathrm{C}-\mathrm{H}$ asymmetric stretching & - & 2925 & 2920 \\
\hline $\mathrm{C}-\mathrm{H}$ symmetric stretching & - & 2853 & 2852 \\
\hline $\mathrm{H}-\mathrm{O}-\mathrm{H}$ bending & 1643 & 1643 & 1636 \\
\hline $\mathrm{CH}_{2}$ scissoring & - & 1469 & 1470 \\
\hline $\mathrm{N}-\mathrm{CH}_{3}$ scissoring & - & 1483 & 1487 \\
\hline Si-O stretching & 1030 & 1032 & 1032 \\
\hline Octahedral sheet & 915 & 915 & 915 \\
\hline Octahedral sheet & 792 & 783 & 775 \\
\hline Si-O-Al bending & 695 & 703 & 685 \\
\hline Si-O bending & 532 & 527 & 531 \\
\hline Si-O-Si bending & 470 & 470 & 471 \\
\hline
\end{tabular}

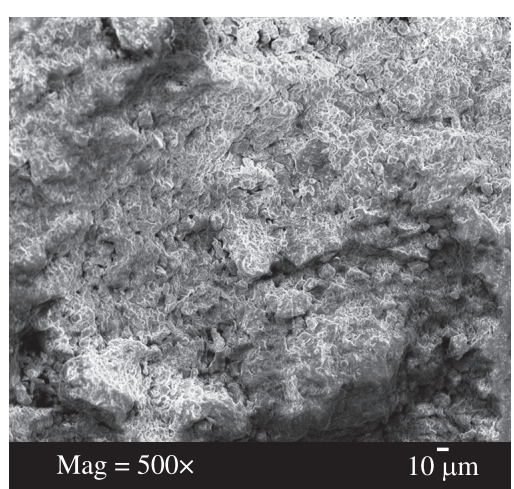

(a)

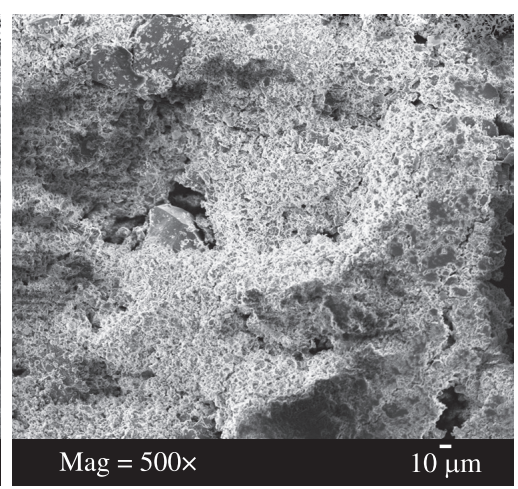

(b)

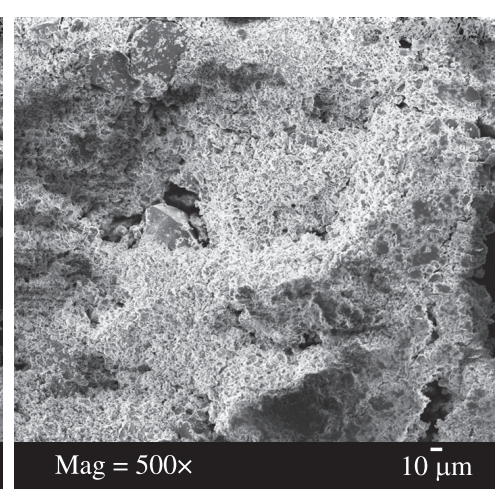

(c)

Figure 2. a) VL-natural; b) VL-benzal; and c) VL-cetyl micrographics clay $500 \times$ amplified. 


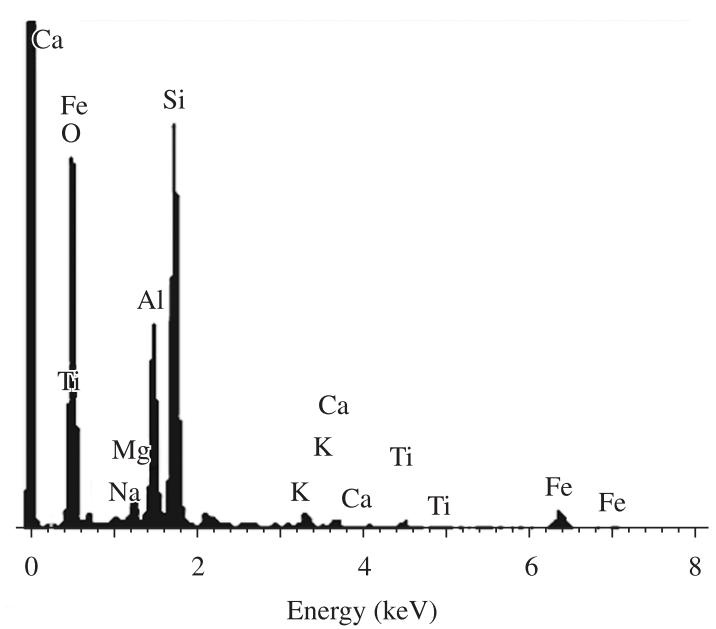

(a)

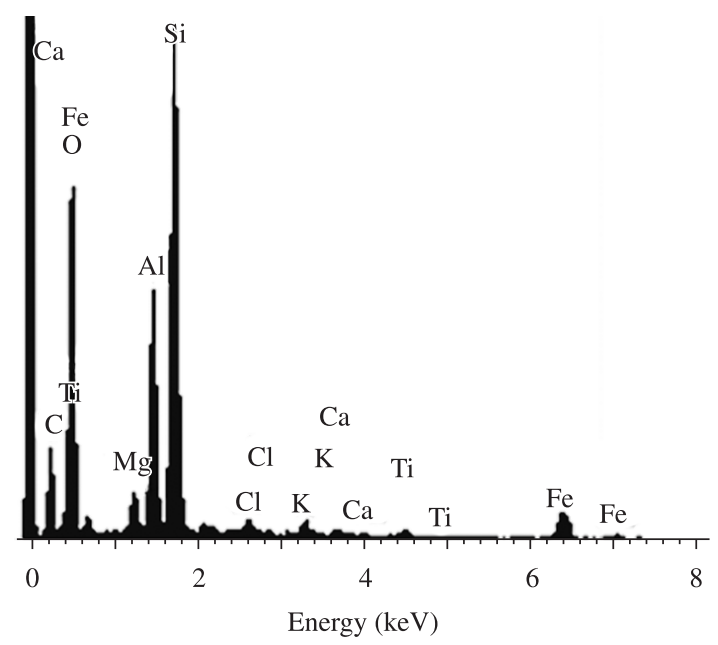

(b)

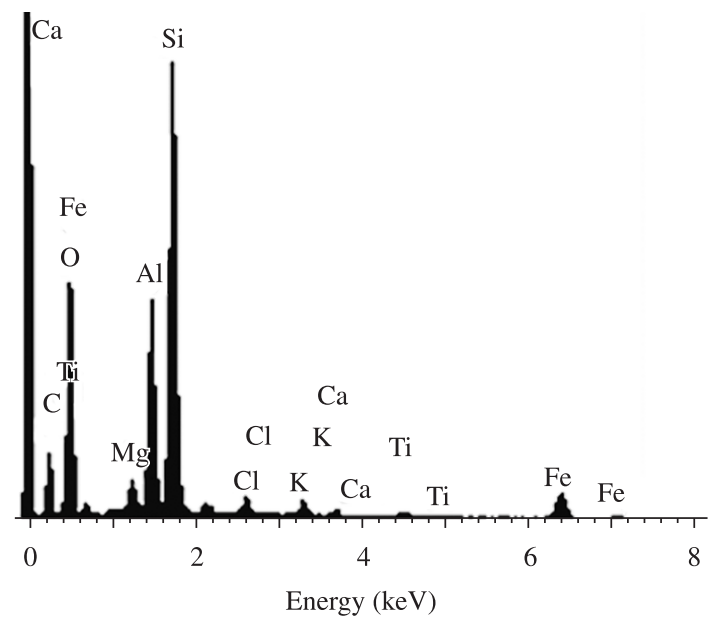

(c)

Figure 3. Chemical composition by energy dispersive X-ray spectroscopy of a) VL-natural; b) VL-benzal; and c) VL-cetyl.
The organoclays presented new characteristic vibrations at 2917 and $2850 \mathrm{~cm}^{-1}$, corresponding to asymmetric and symmetric $\mathrm{CH}_{2}$ stretching modes, and at $1400 \mathrm{~cm}^{-1}$, corresponding to $\mathrm{CH}_{2}$ scissoring ${ }^{32}$. Several studies ${ }^{32-34}$ have related frequency and width of asymmetric $\mathrm{CH}_{2}$ stretching and sensitive to gauche/trans conformer and methylene packing density. Highly ordered characteristic alkylammonium cations (trans conformations) corresponded to C-H stretching shift band location in lower frequencies, low wave number and usually high salt concentrations, whereas low salt concentrations, band location in high frequencies and high wave number corresponded to gauche conformations (chain disorder). Table 2 presents $\mathrm{C}-\mathrm{H}$ stretching band position, where we can observe changes for higher wave number with maximum variations of $8 \mathrm{~cm}^{-1}$ at the asymmetric stretching and $3 \mathrm{~cm}^{-1}$ at the symmetric stretching for VL-benzal clay. The increase in the stretching frequency has indicated gauche chain conformation. This has occurred in both modified clays. The smallest variation in clay symmetric wave number stretching showed this largest band sensibility; similar behavior was observed by $\mathrm{He}$ et al. (2004) $)^{35}$. The $\mathrm{CH}_{2}$ scissoring, corresponding to $1470 \mathrm{~cm}^{-1}$, was also chain disorder indicative.

He et al. (2004) ${ }^{35}$, Xue et al. (2007) $)^{31}$ and Li et al. $(2008)^{36}$ had obtained spectra for organoclays with different salt amounts, observing intensity and band position with the cation exchange capacity. $\mathrm{CH}_{2}$ and $\mathrm{CH}_{3}$ best vibration definition increased with CEC, especially for salt amounts corresponding to twice the amount of clay CEC. The relation 1:1 CEC used in salt amounts for the clays produced in this work, allowed the identification of a $1487 \mathrm{~cm}^{-1}$ band in Table 2, corresponding to $\mathrm{N}-\mathrm{CH}_{3}$ scissoring, a group of alkylammonium chain extremity ${ }^{37}$.

\subsection{Petroleum-derived sorption}

Swelling was not present before the clays were mixed, in contact with petroleum-derived hydrocarbons. This indicates that the stirring is an important factor for compound sorption. VL-natural did not present an expansion for any petroleum derivative, due to the fact that it does not

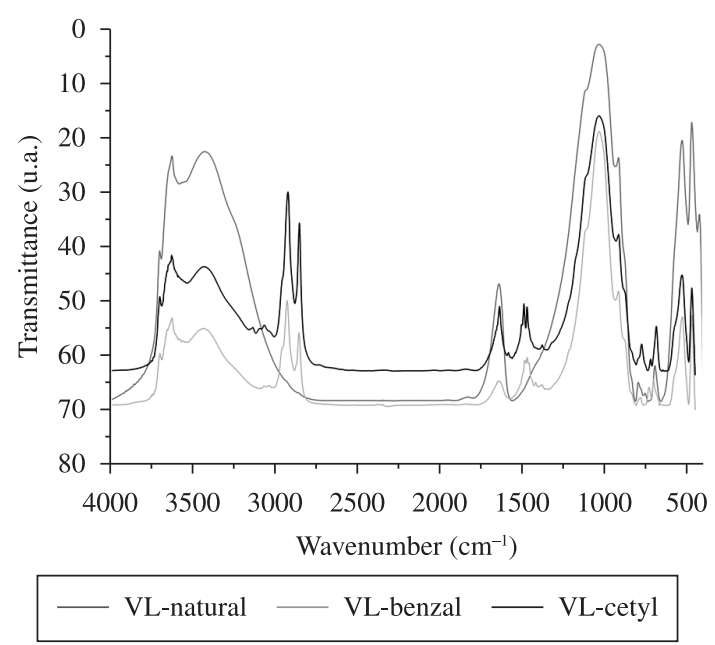

Figure 4. Infrared curves of a) VL-natural; b) VL-benzal; and c) VL-cetyl clays. 
present natural affinity with organic compounds. VL-cetyl clay presented intermediate value (from 6 to $\left.8 \mathrm{~mL} . \mathrm{g}^{-1}\right)^{15}$ for swelling in gasoline and VL-benzal clay presented intermediate value for swelling in diesel oil after 48 hours and after mixing (Figure 5). This analysis characterized organoclays hydrophobicity/organophilicity and the natural clay hydrophilicity/organophobicity.

Gomes $(1988)^{38}$ considers sorption or interaction as dependent on the structure and property of the pollutant, besides the characteristics of clay minerals and exchange cations. While working with clays from Paraiba, Pereira et al. $(2005)^{39}$ also obtained intermediate values in gasoline expansion, whereas Vianna $(2005)^{40}$ attained improved expansion levels reaching high levels for some of the treatments and quaternary ammonium salts used in the preparation of his clays.

Figure 6 shows sorption test results. VL-cetyl showed the largest sorption capacity for gasoline. The sorption value was 3.7 times higher when compared to the VL-natural sorption value for gasoline. The affinity order for VL-natural and VL-cetyl clays was: gasoline > diesel oil, while for VL-benzal clay is reversed (diesel oil $>$ gasoline).

Removal percentage of benzene, toluene and xylene through VL-cetyl was performed, as optimal affinity was assessed at swelling and sorption experiments. The best results of VL-cetyl may be related to linear chain of cetyl-pyridinium chloride salt in comparison with the benzalkonium chloride, as assumed by Jaynes and Vance $(1996)^{41}$.

Table 3 shows removal percentage of compounds by VL-cetyl. The values, considered to be high, indicate the affinity of organophilic clay with the compounds. As gasoline contains approximately 200 different hydrocarbons, aside from additives ${ }^{4}$, and clay interacts with many of these compounds, only BTX have been measured in the present work, with a view to represent the existing affinity between organic compounds and clay. Gasoline sorption test with metal basket resulted in $5.5 \mathrm{~g}$ gasoline/g VL-cetyl, after 48 hours.

Removal percentages correspond to a total of $0.687 \mathrm{mg} \mathrm{BTX} / \mathrm{g}$ organoclay. This value is close to the capacities obtained by Carvalho et al. $(2011)^{42}$ in the removal

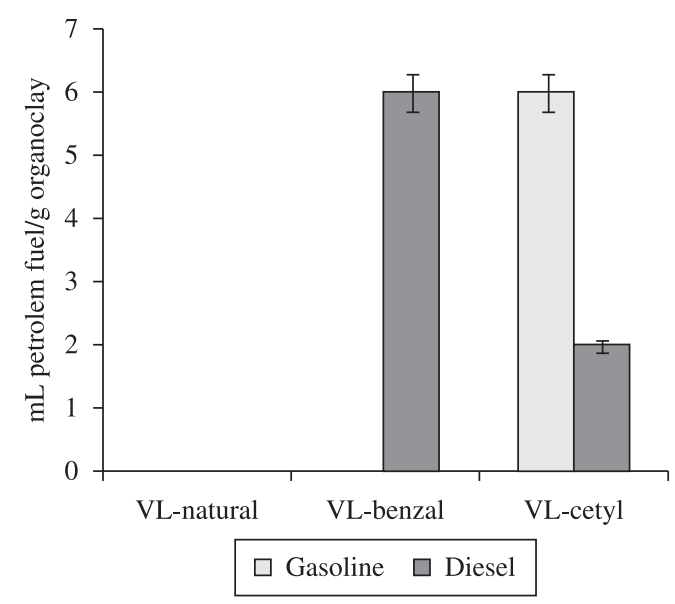

Figure 5. Swelling values after stirring.

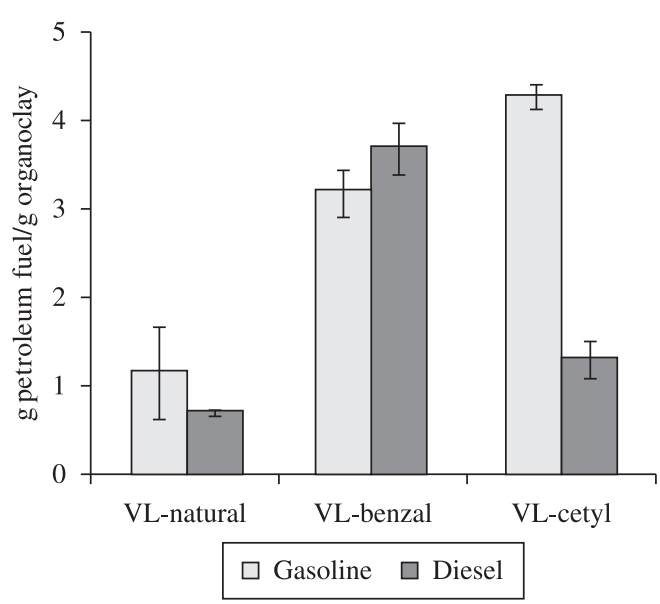

Figure 6. Sorption test.

Table 3. Removal percentage of BTX by VL-cetyl.

\begin{tabular}{ccc}
\hline Compounds & \% removal & mg.g $^{-1}$ adsorbed \\
\hline Benzene & $60.28 \pm 0.32$ & 0.216 \\
Toluene & $60.12 \pm 0.11$ & 0.346 \\
Xylene & $50.38 \pm 0.74$ & 0.125 \\
\hline
\end{tabular}

of m- and p-xylene separately using clays modified with cetyltrimethylammonium chloride, $0.758 \mathrm{mg}$ de $\mathrm{m}$-xylene/g organoclay and 0.765 p-xylene/g organoclay.

The relatively high affinity between BTX and organoclay is probably the result of BTX molecules interacting favorably with the pyridinium ring through $\pi-\pi$ interactions ${ }^{43}$.

The removal percentage test shows good results and the potential use of Brazilian organoclays for sorption of petroleum-derived fuels. The obtained values do not correspond to the maximum sorption capacity of organophilic clays - which should be based on sorption isotherms - although they confirm affinity.

\section{Conclusions}

The results have confirmed the synthesis effectiveness of "Verde-Lodo" organoclay, verified through basal spacing increase, $\mathrm{CH}_{2}$ and $\mathrm{CH}_{3}$ group bands at infrared spectroscopy and carbon and chlorine peaks in the energy dispersive X-ray spectroscopy. The organophilization altered the natural hydrophilic character to hydrophobic and organophilic. Modifications occurred in clays due to inorganic cations changes into organic cations, which caused interlayer space features to enable the organic compound interaction, whose likeness for the clays was confirmed at swelling and sorption tests. The removal percentages of BTX show that the organoclays presented potential for environmental remediation, such as petroleum-derived fuels sorption in the form of barrier systems or adsorption systems.

\section{Acknowledgements}

The authors acknowledge the financial support granted by CNPq and FAPESP. 


\section{References}

1. Tiburtius ERL, Peralta-Zamora PP, Emmel A and Leal ES. Treatment of gasoline-contaminated waters by advanced oxidation processes. Journal of Hazardous Materials B. 2005; 126:86-90. PMid:16051429. http://dx.doi. org/10.1016/j.jhazmat.2005.06.003

2. Corseuil HX, Hunt CS, Santos RCF and Alvarez PJJ. The influence of the gasoline oxygenate ethanol on aerobic and anaerobic BTX biodegradation. Water Research. 1998; 32:20652072. http://dx.doi.org/10.1016/S0043-1354(97)00438-7

3. Companhia de Tecnologia de Saneamento Ambiental CETESB. Áreas contaminadas novembro 2008. Available from: <http://www.cetesb.sp.gov.br/Solo/areas_contaminadas/ relacao_areas.asp $>$

4. Gitipour S, Bowers MT, Hufft W and Bodocsi A. The efficiency of modified bentonite clays for removal of aromatic organics from oily liquid wastes. Spill Science \& Technology Bulletin. 1997; 4(3):155-164. http://dx.doi.org/10.1016/S13532561(98)00012-7

5. Nakhla G. Biokinetic modeling of in situ bioremediation of BTX compounds - impact of process variables and scaleup implications. Water Research. 2003; 37:1296-1307. http:// dx.doi.org/10.1016/S0043-1354(02)00491-8

6. Watts RJ, Haller DR, Jones AP and Teel AL. A foundation for the risk-based treatment of gasoline-contaminated soils using modified Fenton's reactions. Journal of Hazardous Materials B. 2000; 76:73-89. http://dx.doi.org/10.1016/S03043894(00)00173-4

7. Nunes CC and Corseuil HX. Importância do etanol na atenuação natural de águas subterrâneas impactadas por gasolina. Engenharia Sanitária Ambiental. 2007; 12(3):259265. http://dx.doi.org/10.1590/S1413-41522007000300005

8. Zhou Q, Hea HP, Zhua JX, Shen W, Frost RL and Yuan P. Mechanism of p-nitrophenol adsorption from aqueous solution by HDTMA+-pillared montmorillonite - Implications for water purification. Journal of Hazardous Materials. 2008; 154:10251032. PMid:18082948. http://dx.doi.org/10.1016/j. jhazmat.2007.11.009

9. Xu L, Zhu L. Structures of OTMA- and DODMA-bentonite and their sorption characteristics towards organic compounds. Journal of Colloid and Interface Science. 2009; 331:8-14. PMid:19081110. http://dx.doi.org/10.1016/j.jcis.2008.11.030

10. Patel HA, Bajaj HC and Jasra RV. Sorption of Nitrobenzene from Aqueous Solution on Organoclays in Batch and Fixed-Bed Systems. Industrial \& Engineering Chemistry Research. 2009; 48:1051-1058. http://dx.doi.org/10.1021/ ie800953g

11. Cavalcanti JVFL, Abreu CAM and Motta Sobrinho MA. Preparação e utilização de uma argila esmectítica organofílica como adsorvente de fenol. Química Nova. 2009; 36(2):1-7.

12. Wagner J, Chen H, Brownawell BJ and Westall JC. Use of cationic surfactants to modify soil surfaces to promote sorption and retard migration of hydrophobic organic compounds. Environmental Science Technology. 1994; 28:231-237. http:// dx.doi.org/10.1021/es00051a008

13. Burns SE, Bartelt-Hunt SL and Smith JA. Sorption and permeability of gasoline hydrocarbons in organobentonite porous media. Journal of Hazardous Materials. 2003; 96:9197. http://dx.doi.org/10.1016/S0304-3894(02)00199-1

14. Pereira KRO. Ativação ácida e preparação de argilas organofílicas partindo-se de argila esmectítica proveniente do Estado da Paraíba. [Tese]. São Paulo: Escola Politécnica da Universidade de São Paulo; 2003.
15. Diaz FRV. Preparação em nível de laboratório de algumas argilas esmectíticas organofílicas. [Tese]. São Paulo: Escola Politécnica da Universidade de São Paulo; 1994.

16. Lee JF, Mortland MM, Chiou CT, Kile DE and Boyd SA. Adsorption of benzene, toluene, and xylene by Two tetramethylammonium-smectites having Different charge densities. Clays and Clay Minerals. 1990; 38:113-120. http:// dx.doi.org/10.1346/CCMN.1990.0380201

17. Kowalska M, Güler H and Cocke DL. Interactions of clay minerals with organic pollutants. The Science of the Total Environment. 1994; 141:223-240. http://dx.doi. org/10.1016/0048-9697(94)90030-2

18. Santos PS. Ciência e Tecnologia de Argilas. São Paulo: Editora Edgard Blücher Ltda.; 1992. v. 1-3.

19. Guarino AWS, San Gil RAS, Polivanov H and Menezes SMC. Characterization of a Brazilian Smectite by Solid State NMR and X-Ray Diffraction Techniques. Journal of the Brazilian Chemical Society. 1997; 8(6):581-586. http://dx.doi. org/10.1590/S0103-50531997000600004

20. Pereira KRO. Estudo, em escala de laboratório, do uso de argilas do tipo bofe na obtenção de argilas organofilicas $e$ ativadas. [Tese]. São Paulo: Escola Politécnica da Universidade de São Paulo; 2008.

21. Foster MD. Geochemical studies of clay minerals III. The determination of free silica and free alumina in montmorillonites. Geochimica et Cosmochimica Acta. 1953; 3:143-154. http:// dx.doi.org/10.1016/0016-7037(53)90003-9

22. American Society for Testing and Materials - ASTM. ASTM F716-82: Standard methods of testing sorbent performance of absorbents. West Conshohocken; 1993. 5 p.

23. American Society for Testing and Materials - ASTM. ASTM F726-99: Standard test method for sorbent performance of adsorbents. West Conshohocken; 1999. 6 p.

24. Tanobe VRL, Pereira MFR, Sydenstriker THD, Amico SC and Vargas JVC. In: Anais do 3th Congresso Brasileiro de $P \& D$ em Petróleo e Gás; 2005; Salvador. IBP; 2005.

25. 25. Lagaly G. Layer charge heterogeneity in vermiculites. Clays and Clay Minerals. 1982; 30:215-222. http://dx.doi. org/10.1346/CCMN.1982.0300308

26. Gomez JG, Garcia AM, Diez MAD, Garcia CG and Rey ES. Preparation and characterization of activated carbons from impregnation pitch by $\mathrm{ZnCl}_{2}$. Applied Surface Science. 2006; 252:5976-5979. http://dx.doi.org/10.1016/j. apsusc.2005.11.011

27. Wang C-C, Juang L-C, Lee C-K, Hsu T-C, Lee J-F and Chao H-P. Effects of exchanged surfactant cations on the pore structure and adsorption characteristics of montmorillonite. Journal of Colloid and Interface Science. 2004; 280:27-35. PMid:15476770. http://dx.doi.org/10.1016/j.jcis.2004.07.009

28. He H, Zhou Q, Martens WN, Kloprogge TJ, Yuan P, Xi Y et al. Microstructure of HDTMA+-modified montmorillonite and its influence on sorption characteristics. Clays and Clay Minerals. 2006; 54:689-696. http://dx.doi.org/10.1346/ CCMN.2006.0540604

29. Zhang WA, Chen DZ, Xu HY, Shen XF and Fang YE. Influence of four different types of organophilic clay on the morphology and thermal properties of polystyrene/clay nanocomposites prepared by using the $\gamma$-ray irradiation technique. European Polymer Journal. 2003; 39:2323-2328. http://dx.doi. org/10.1016/j.eurpolymj.2003.08.006

30. Bala P, Samantaray BK and Srivastava SK. Synthesis and characterization of Na-montmorillonite-alkylammonium 
intercalation compounds. Materials Research Bulletin. 2000; 35:1717-1724. http://dx.doi.org/10.1016/ S0025-5408(00)00368-8

31. Xue W, He H, Zhu J and Yuan P. FTIR investigation of CTAB-Al-montmorillonite complexes. Spectrochimica Acta Part A. 2007; 67:1030-1036. PMid:17289428. http://dx.doi. org/10.1016/j.saa.2006.09.024

32. Vaia RA, Teukolsky RK and Giannelis EP. Interlayer Structure and Molecular Environment of Alkylammonium Layered Silicates. Chemistry of Materials. 1994; 6:1017-1022. http:// dx.doi.org/10.1021/cm00043a025

33. Mendelsohn R, Brauner JW and Gericke A. External Infrared Reflection Absorption Spectrometry of Monolayer Films at the Air-Water Interface. Annual review of physical chemistry. 1995; 46:305-334. http://dx.doi.org/10.1146/ annurev.pc.46.100195.001513

34. Li Y and Ishida H. Concentration-Dependent Conformation of Alkyl Tail in the Nanoconfined Space: Hexadecylamine in the Silicate Galleries. Langmuir. 2003; 19:2479-2484. http:// dx.doi.org/10.1021/la026481c

35. He H, Frost LR and Zhu J. ${ }^{29} \mathrm{Si}$ and ${ }^{27} \mathrm{Al}$ MAS NMR spectra of mullites from different kaolinites Spectrochimica Acta Part A. 2004; 60:2853-2859. http://dx.doi.org/10.1016/S13861425(03)00337-8

36. Li Z, Jiang W-T and Hong H. An FTIR investigation of hexadecyltrimethylammonium intercalation into rectorite. Spectrochemica Acta Part A. 2008; 71:1525-1534. PMid:18573686. http://dx.doi.org/10.1016/j.saa.2008.05.015
37. Venkataraman NV and Vasudevan S. nterdigitation of an Intercalated Surfactant Bilayer. Journal of Physical Chemistry B. 2001; 105:7639-7650. http://dx.doi.org/10.1021/jp0105802

38. Gomes CF. Argilas: o que são e para que servem. Lisboa: Fundação Calouste Gulbenkian; 1988. 457 p.

39. Pereira KRO, Hanna RA, Vianna MMGR, Pinto CA, Rodrigues MGF and Díaz FRV. Brazilian organoclays as nanostructured sorbents of petroleum-derived hydrocarbons. Materials Research. 2005; 8(1):77-80. http://dx.doi.org/10.1590/S151614392005000100014

40. Vianna MMGR. Desenvolvimento de argilas organofílicas visando a remediação de áreas contaminadas por componentes da gasolina. [Tese]. São Paulo: Escola Politécnica da Universidade de São Paulo; 2005.

41. Jaynes WF and Vance GF. BTEX Sorption by OrganoClays: Cosorptive Enhancement and Equivalence of Interlayer Complexes. Soil Science Society of America Journal. 1996; 60:1742-1749. http://dx.doi.org/10.2136/ sssaj1996.03615995006000060019x

42. Carvalho MN, Silva DDC, Santos JCP, Abreu CAM and Motta M. In: Anais do 26th Congresso Brasileiro de Engenharia Sanitária e Ambiental; 2011; Porto Alegre. Associação Brasileira da Engenharia Sanitária e Ambiental; 2011.

43. Huang HC, Lee JF, Chao HP, Yeh PW, Yang YF and Liao WL. The influences of solid-phase organic constituents on the partition of aliphatic and aromatic organic contaminants. Journal of Colloid and Interface Science. 2005; 286:127-133. PMid:15848409. http://dx.doi.org/10.1016/j.jcis.2005.01.042 